重なっているとすれば，これをただちに相転移の影綿であるとは いえない。 $\mathrm{HEX}-\mathrm{BF}_{4}$ ではまったく不連続は見られない( ${ }^{19} \mathrm{~F} の$ $T_{1}$ が鈢小になる温度で ${ }^{1} \mathrm{H}$ の $T_{1}$ にわずかに不連続があるがこ の温度は枟移点より上である)。さらに $T_{1} \rho$ にはすべてまったく
不連続は認められないので，秩序一無秩序転移の温度と陽子共鳴 の線幅転移の温度が等しいことは単なる偶然であると思われる。 終りに，著者の一人(伊藤)は，種々の有益な助言と励ましを与 えて下さった小林 宏助教授に深く感謝致します。

\title{
ユーロピウム $(\mathrm{III})-\mathbf{D}-$ グルコサミン酸錯体のポーラログラフィー
}

(昭和 44 年 1 月 6 日受理)

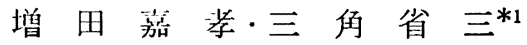

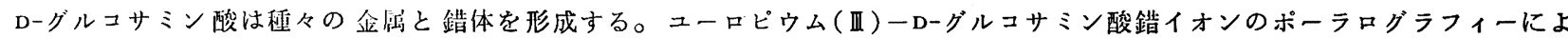
り，その電極過程および電極近傍におけるイオン種および速度定数 $\left(k_{f}^{0}\right)_{\mathrm{B}}$ を求めた。また $p \mathrm{H}$ 滴定によって溶液中に $[\mathrm{EuG}]^{2+}$, $\left[\mathrm{Eu}(\mathrm{G})_{2}\right]+$ および $[\mathrm{EuG}(\mathrm{OH})]^{+}$の䤧イオン㜞の存在を認めた。Bjerrum 方法によって生成定数を算定すると $\log K_{1}=5.24 ， \log$ $K_{1} K_{2}=10.52$ をえた。

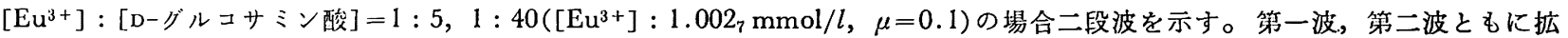
散徘速で，符一波は非可逆性の一霆子㬊元，また第二波は溶液中の水素イオンに依存し，鍇体の加水分解によって生じた水素イオ ンの巡元で生ずる。10.15<pH<10.8 においては半波電位は移行しない。

$p \mathrm{H}=10.5, \mu=0.1\left(\mathrm{NaClO}_{4}\right)$ において電極過程は

$$
\begin{aligned}
& {\left[\mathrm{Eu}(\mathrm{G})_{2}\right]^{+} \rightleftarrows[\mathrm{EuG}]^{2+}+\mathrm{G}^{-}} \\
& {[\mathrm{EuG}]^{2+}+e \stackrel{\left(k_{f}^{0}\right)_{\mathbf{B}}}{\longrightarrow}[\mathrm{EuG}]^{+}}
\end{aligned}
$$

速洨分数 $\left(k_{f}^{0}\right)_{\mathrm{B}}=2.05 \times 10^{-15} \mathrm{~cm} / \mathrm{sec}\left(\left[\mathrm{Eu}^{3+}\right]:\left[\mathrm{G}^{0}\right]=1: 5\right), 3.24 \times 10^{-17} \mathrm{~cm} / \mathrm{sec}\left(\left[\mathrm{Eu}^{3+}\right]:\left[\mathrm{G}^{0}\right]=1: 40\right)$ をえる。なお $\mathrm{d} V / \mathrm{d} t$ $=f(V)$ 線は $p \mathrm{H}=10.5$ において還元側の切れ込み一つおよび酸化側に一つ認められる。また NMR の結果から D-グルコサミ ン酸のポリ水酸基の酸素が金属との相互作用を有する可能性が認められる。

\section{1 緒言}

D-グルコサミン酸湓と金属との反応による一連の砸究が， Gergely ら1)によってなされ，第一透移金属とD-グルコサミン酸 との鉆体形成反応をポーラログラフィー法, 電位差滴定法によっ て研究し，金属の安定度の順序を報告している。またTamura

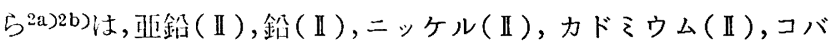

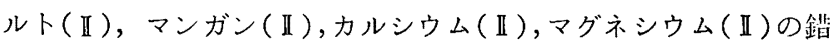

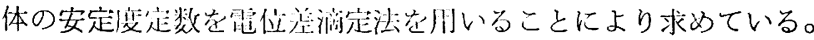

本研笃に米いて著者らはDーグルコサミン酸とユーロピウム(II) との䤮体を作成させ，その性質について梌討を試みた。すなわち

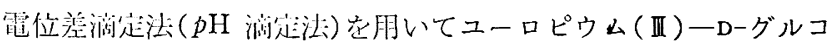

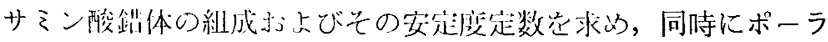

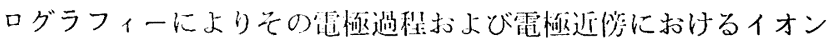

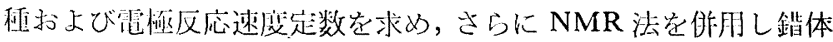
の構造を明らかにした。

\section{2 実験}

\section{1 試 薬}

*1 Yoshitaka MAsudA, Seizo Misumi 九州大学理学部化 学教空, 福侗戗箱岮町

1) A. Gergely, P. Szarvas, L. Maczag, Magy. Kem. Folyoirat, 70, (6), 235(1964); A. Gergely, P. Szarvas, I. Korondan, Acta Chim. Acad. Sci. Hung., 26, 313 (1961).

2) a) Z. Tamura, M. Miyazaki, Chem. Pharm. Bull. (Tokyo), 13, 387(1965).

b) Z. Tamura, M. Miyazaki, ibid., 14, 114(1966).
D-グルコサミン酸(東京化成株式会社製, 特級, mp $250^{\circ} \mathrm{G}$ )を 1 週問真空乾燥して科量し, 原液 $0.05 \mathrm{~mol} / l$ 溶液をつくった。 ポーラログラフィーのさいにはナトリウム塩とするために水酸化 ナトリウム $0.05 \mathrm{~mol} / l$ 溶液を過剩に加え, Dーグルコサミン酸ナ トリウム壏 $0.05 \mathrm{~mol} / l$ とした。

ユーロピウム (III)の原液は $\mathrm{Eu}_{2} \mathrm{O}_{3}(99.999 \%$ 純度)を少量の過 䘏素酸に溶解させ, 完全にユーロピウム過塩素酸塩に変化させて つくった。その原液浱度は $1.002_{7} \times 10^{-2} \mathrm{~mol} / l$ であった。これ は重量法および EDTA 滴定法を用いて决定した。

$p \mathrm{H}$ 滴定は炭酸イオンを含まない水酸化カリウム溶液を Armstrong の方法3)にしたがって調製した。イオン強度を一定にする ために過䘏糸酸ナトリウム ( 3 回再結晶)を使用した。なお $p \mathrm{H} の$ 調節には $0.1 \mathrm{~mol} / l$ 塭酸溶液と $0.1 \mathrm{~mol} / l$ 水酸化ナトリウム溶液 とを使用した。

また NMR 測定には $\mathrm{D}_{2} \mathrm{O}$ (Merk Germann Importer Nakarai Chemical Ltd.), 塩化テトラエチルアンモニウム(東京化成, 標 準物質)を用いた。

\section{2 装}

柳本製交直両用ポーラログラフ P 102 型および H 型セルを用 いすべて対 SCE に参照した。また $p \mathrm{H}$ 調整のために日立製

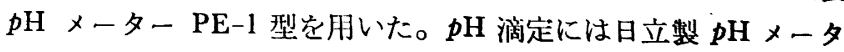
一P型を用いた。

水銀柱の高さ $68.7 \mathrm{~cm}$ で使用した毛細管について，毛細管定数 は $m^{2 / 3} \cdot t^{1 / 6}=1.774 \mathrm{mg}^{2 / 3} \cdot \mathrm{sec}^{1 / 6}(-1.45 \mathrm{~V}$ vs. SCE)であった。オ ッシロポーラログラフィーの测定にはポーラロスコープP 576 を 使仃した。i〜 $t$ 曲綠の测定には，標準抵抗 $( \pm 0.5 \%, 0 \sim 1 \mathrm{M} \Omega)$,

3) D. M. G. Armstrong, Chem. Ind. (London), 1955, 1405. 
シンクロスコープ SS-5302(岩崎通信機)を用いた。また電位の設 定には Beckmann 電位差計を用い，X線フィルムを用い $35 \mathrm{~mm}$ Cannonカメラで撮影した。NMR の測定には Varian 60 を使用 した。测定には $\left[\mathrm{Eu}^{3+}\right]:\left[\mathrm{G}^{0}\right]=1: 5\left(\left[\mathrm{Eu}^{3+}\right]=0.04 \mathrm{~mol} / l\right)$, 水 酸化ナトリウム粉末，塩化テトラメチルアンモニウム(内部標準) を使用し， $\mathrm{D}_{2} \mathrm{O}$ (重水)に溶かしたものを用いた。

\section{3 結 果と考察}

\section{$3.1 \mathrm{pH}$ 滴定}

3.1 .1 理論と実験：D-グルコサミン酸 $\mathrm{HOCH}_{2}(\mathrm{CHOH})_{3} \mathrm{CH}$ $\mathrm{NH}_{2} \mathrm{COOH}$ は溶液中で両性電船質として存在する。すなわちつ ぎの反応式で示される。

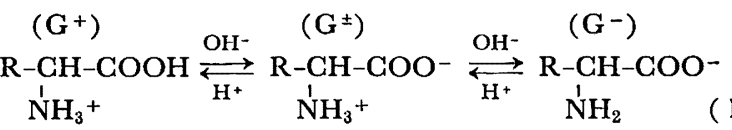
赤堀の式4)を用いると $p k_{1}, p k_{2}$ は

$$
\begin{aligned}
& p k_{1}=p \mathrm{H}-\log \left(\frac{C}{C_{1}-\left[\mathrm{H}^{+}\right]}-1\right) \\
& p k_{2}=p \mathrm{H}+\log \left(\frac{C}{C_{2}-\left[\mathrm{H}^{+}\right]}-1\right)
\end{aligned}
$$

ここで $C_{1}$ は溶液中の酸の全搌度， $C_{2}$ は溶液中の塩基の全搌屡， $C$ はグルコサミン酸の全裖度である。

グルコサミン酸の $p k_{2}$ は田村2)によると $9.06\left(30\right.$ 土0.5 $\left.{ }^{\circ} \mathrm{C}\right)$, Gergely によると $p k_{2}$ は 9.24 であるが，著者らは滴定曲線から 9.289 $\left(25 \pm 0.1^{\circ} \mathrm{C}\right)$ をえた。えられた滴定曲線を図1 1 に示した。 さらに瀜定曲線を用いて 安定度定数を求放るために次式を用い た。

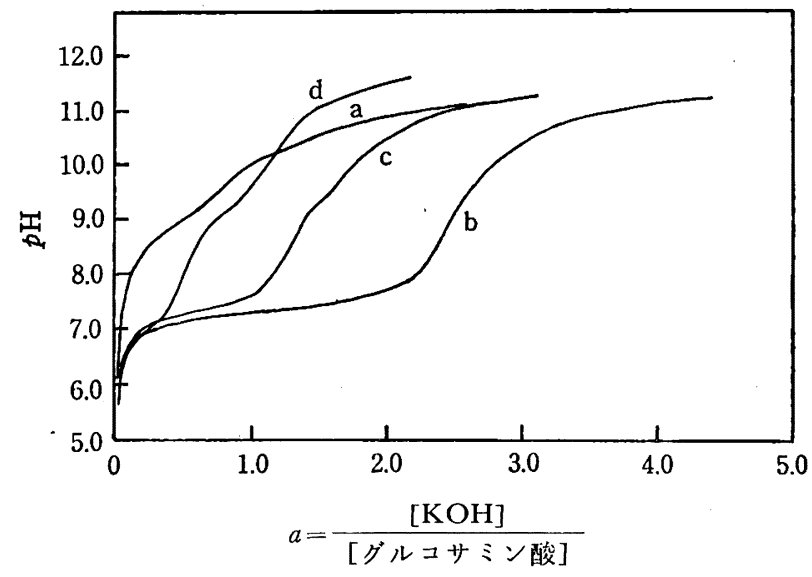

図 $1 \quad p \mathrm{H}$ 滴 定 曲? 線

Dーグルコサミン酸は溶液中では雨性イオンとして存在してい る。

い屯遊雄した水素イオンとグルコサミン酸と結合した水絜イオ ンの全箎度 $\left[\mathrm{H}_{0}{ }^{+}\right]$はつぎの二つの方法で表わされる。

$$
\begin{gathered}
{\left[\mathrm{H}_{0}{ }^{+}\right]=\left[\mathrm{H}^{+}\right]+\left[\mathrm{G}^{ \pm}\right]-\left[\mathrm{OH}^{-}\right]} \\
{\left[\mathrm{H}_{0}{ }^{+}\right]=\left[\mathrm{G}^{0}\right]-[\mathrm{KOH}]} \\
\mathrm{G}^{0}=\mathrm{R}-\mathrm{CH}-\mathrm{COOH} \\
\mathrm{NH}_{2}
\end{gathered}
$$

でデす。

4）赤屈四郎，“アミノ酸および蛋白質”，步立出版(1944)p. 386.
(2)式と(3)式とから

$$
\begin{aligned}
& {\left[\mathrm{G}^{ \pm}\right]=\left[\mathrm{G}^{0}\right]-[\mathrm{KOH}]-\left[\mathrm{H}^{+}\right]+\left[\mathrm{OH}^{-}\right]} \\
& {\left[\mathrm{G}^{ \pm}\right]=\left(\left[\mathrm{H}^{+}\right]\left[\mathrm{G}^{-}\right]\right) / k_{2}}
\end{aligned}
$$

(4)式に(5)式を代入与をと

$$
\left(\left[\mathrm{H}^{+}\right]\left[\mathrm{G}^{-}\right]\right) / k_{2}=\left[\mathrm{G}^{0}\right]-[\mathrm{KOH}]-\left[\mathrm{H}^{+}\right]+\left[\mathrm{OH}^{-}\right]
$$
をえる。

この両辺の対数をとっと

$$
\begin{aligned}
\log \left[\mathrm{G}^{-}\right] & =\log \left\{\left[\mathrm{G}^{0}\right]-[\mathrm{KOH}]\right. \\
& \left.-\left[\mathrm{H}^{+}\right]+\left[\mathrm{OH}^{-}\right]\right\}-\log \left[\mathrm{H}^{*}\right] / k_{2}
\end{aligned}
$$

いま金属 $\left(\mathrm{M}^{3+}\right)$ とグルコサミン酸が $1: 1 ， 1: 20$ 遂次鉷休它形 成するときに(7)式が成立与る。

$$
\left[\mathrm{G}^{0}\right]=\left[\mathrm{G}^{-}\right]+\left[\mathrm{G}^{ \pm}\right]+\left[\mathrm{G} \cdot \mathrm{M}^{2+}\right]+2\left[(\mathrm{G})_{2} \mathrm{M}^{+}\right]
$$

1 個の金属と絬合した配位子(グルコサミン酸)の头地分子数在 $\bar{n}$ とすると

$$
\bar{n}=\left\{\left[\mathrm{G} \cdot \mathrm{M}^{2+}\right]+2\left[(\mathrm{G})_{2} \mathrm{M}^{+}\right]\right\} /\left[\mathrm{M}_{0}\right]
$$

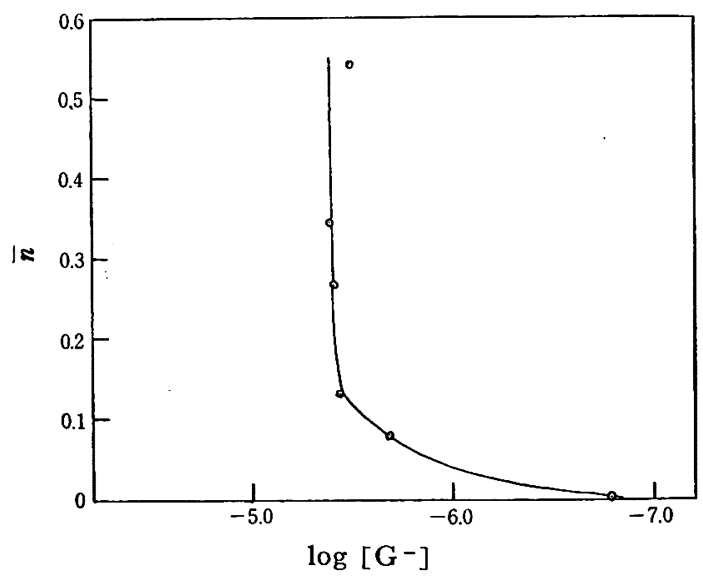

$\left[\mathrm{Eu}^{3+}\right]:\left[\mathrm{G}^{0}\right]=1: 1, \quad \mu=0.1\left(\mathrm{NaClO}_{4}\right)$

図 2-a 生成 曲線

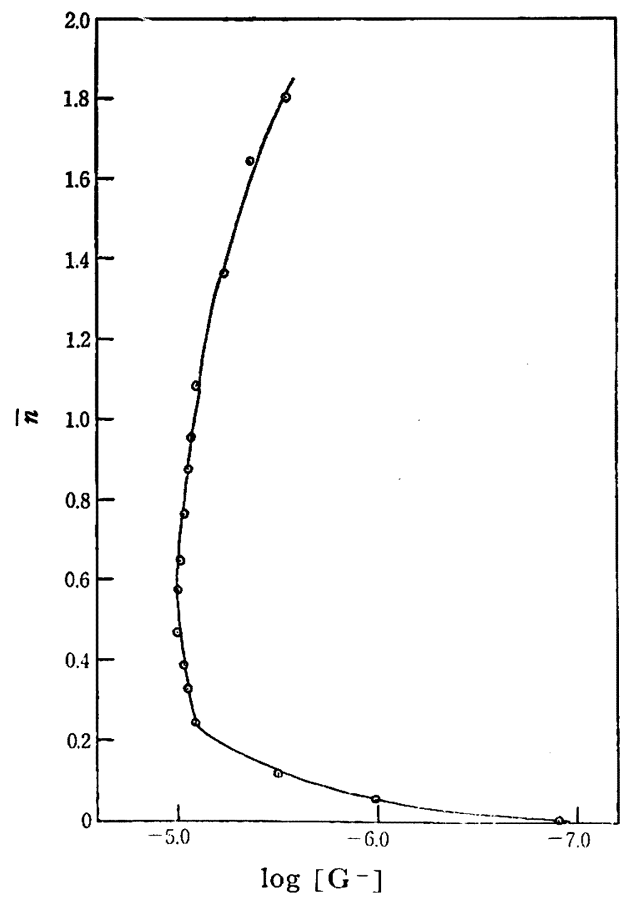

$\left[\mathrm{Eu}^{3+}\right]:\left[\mathrm{G}^{\prime}\right]=1: 2, \quad \ell=0.1\left(\mathrm{NaClO}_{4}\right)$ 図 2-b 生成曲線 


$$
\begin{aligned}
& {\left[\mathrm{G}^{0}\right]=\left[\mathrm{G}^{-}\right]\left(1+\left\{\left[\mathrm{H}^{+}\right] / k_{2}\right\}\right)+\bar{n}\left[\mathrm{M}_{0}\right] } \\
& Q= 1+\left(\left[\mathrm{H}^{+}\right] / k_{2}\right) \text { とおくと } \\
& \bar{n}=\left\{\left[\mathrm{G}^{0}\right]-Q\left[\mathrm{G}^{-}\right]\right\} /\left[\mathrm{M}_{0}\right] \\
& \text { ここで }\left[\mathrm{G}^{0}\right]: \text { グルコサミン酸の全篮度, }\left[\mathrm{M}_{0}\right] \text { はユーロピウム }
\end{aligned}
$$

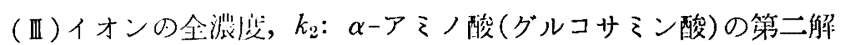
惟定数定示与。(10)式と（6)式を用い $\left[\mathrm{G}^{-}\right]$と $\bar{n}$ を求めると Irving, Rossotti の式5)によって遂次生成定数を求めうる。

$$
\begin{aligned}
& K_{1}=\bar{n} /\left\{(1-\bar{n})\left[\mathrm{G}^{-}\right]\right\} \\
& K_{2}=(\bar{n}-1) /\left\{(2-\bar{n})\left[\mathrm{G}^{-}\right]\right\}
\end{aligned}
$$

この式を用い図 2 の a , b のグラフから遂次安定度定数を求め た。

$0.05 \mathrm{~mol} / l \mathrm{D}$ グルコサミン酸を $2 \mathrm{ml}$ とり, $\mu=0.1\left(\mathrm{NaClO}_{4}\right)$ とし，全是を $100 \mathrm{ml}$ とし，空秦ガスを 30 分間通気し，脱二酸化 炭素を行なった。これを $0.109_{7} \mathrm{~mol} / l$ 水酸化ナトリウム溶液で $p \mathrm{H}$ 润定した(図10 日 に示す)。この曲線から $p k_{2}=9.28_{9}$ をえ た。さらにユーロピウム（II)の $0.010027 \mathrm{~mol} / l$ を $10 \mathrm{ml}$ とり， $\mathrm{D}$-グルコサミン酸 $(0.05 \mathrm{~mol} / l)$ を $2,4,10 \mathrm{ml}$ 添加し, イオン強 度 $\mu=0.1\left(\mathrm{NaClO}_{4}\right)$ にし, 全量を $100 \mathrm{ml}$ にする。これを前と同 栐に等秦ガスを近父し，それでれ $0.109_{7} \mathrm{~mol} / l$ 水酸化カリウム 溶液で润走を行なった。えられた曲線(すべて体積補正を行なっ たもの)図 1 の b c , d に示した。

3.1 .2 安定度定数の計算：（11)，(12)式から図 2-a， b のグ ラフを䏘いて安定度定数を計算した。 $\log K_{1}$ の平均值は 5.24 , および総合安定度定数 $\log K_{1} K_{2}=10.52$ をえた。さらに加水分解 によって生成与る鈚体を考え，四村2) の式を用いて 鍇イオン種 $[\mathrm{EuG}(\mathrm{OH})]+$ +加水分解定数を求めた。

$p \mathrm{H}=8.05_{8} ， 8.62_{0} ， 8.90_{2}$ においてそれぞれ $K_{\mathrm{EuGOH}}=9.35_{4} \times$ $10^{-9}, 4.15_{7} \times 10^{-9}, 3.47_{6} \times 10^{-9}$ をえた。

溶液中の鈚イオン種の存在を $p \mathrm{H}$ 滴定法によって決定した。溶 泣中には $[\mathrm{EuG}]^{2+},\left[\mathrm{Eu}(\mathrm{G})_{2}\right]^{+},[\mathrm{EuG}(\mathrm{OH})]^{+}$などの錯イオン 種が存在することが俧められた。

\section{2 ポーラログラフィー}

3.2 .1 操 作 : ユーロピウム (II ) $1.0027 \mathrm{mmol} / l$ (最終浱度) にグルコサミン酸イオン $4 \sim 40 \mathrm{mmol} / l$ と変化させ, $0.1 \mathrm{~mol} / l$ 水酸化ナトリウム才うよ゙゙ $0.1 \mathrm{~mol} / l$ 塩酸を使用して $p \mathrm{H}$ を 8.0 11.2 の领城で変化させ， $\mu=0.1\left(\mathrm{NaClO}_{4}\right)$, 全量を $10 \mathrm{~m} l$ に蒸

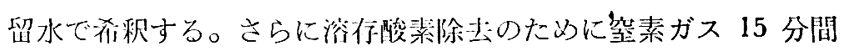
迥気してポーラログラム壳とった $\left(\mathrm{m}^{2 / 3} \cdot t^{1 / 6}=1.774 \mathrm{mg}^{1 / 3} \cdot \mathrm{sec}^{1 / 6}\right.$ $(-1.45 \mathrm{~V}$ vs. SCE))。

3.2 .2 ポーラログラフ波: ユーロピウム(价)浪度 $1.0027 \mathrm{mmol}$

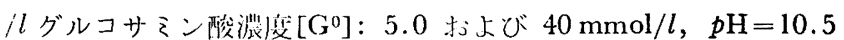
で典型的なポーラログラム它えた(悩 3 参照)。前者は二段波で第 一波の半波電位は $-1.381 \mathrm{~V}$ vs. SCE に，また第二波の半波電位 は $-1.575 \mathrm{~V}$ vs. SCE にえられた(䌽 3 のa)。後者は一段波で，

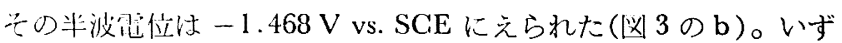

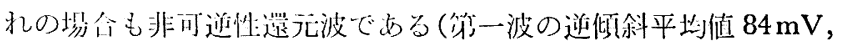

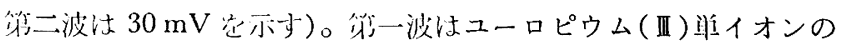

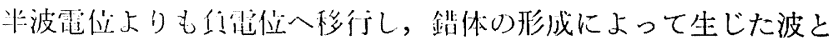

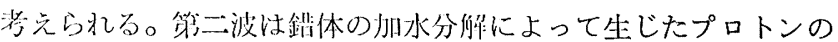
遇元波と推篷さ机る。

5) H. M. Irving, H. S. Rossotti, J. Chem. Soc., 1954, 2904.

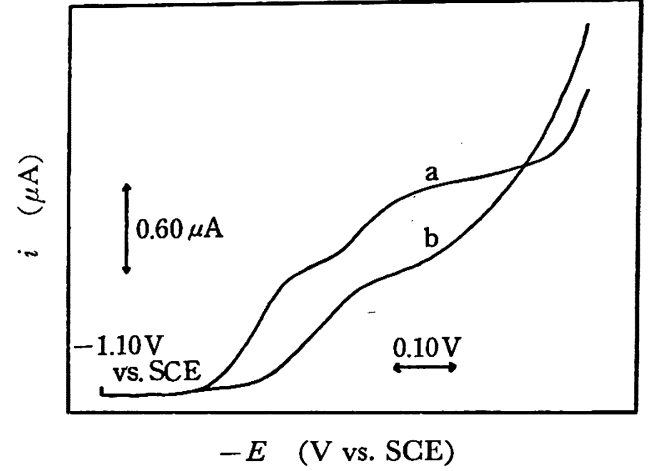

$\begin{array}{crccc} & p \mathrm{H} & {\left[\mathrm{Eu}^{3+}\right](\mathrm{mmol} / l)} & {\left[\mathrm{G}^{0}\right](\mathrm{mmol} / l)} & \mu\left(\mathrm{NaClO}_{4}\right) \\ \text { a } & 10.5 & 1.002_{7} & 5 & 0.1 \\ \text { b } & 10.5 & 1.002_{7} & 40 & 0.1\end{array}$

図 3 ポーラログラム

3.2 .3 水銀柱の高さの影響：極大波が消失し，半波電位の移 行のない $p \mathrm{H}=10.5$ において限界電流におよぼす水銀柱の高さの 影響について検討した結果を表 1 に示す。いずれにおいても限界 電流は水銀柱の高さ(逆圧補正)の平方根に比例し, 電極反応は拡 散律速である。

\section{表 1 水銀柱の问さの影響}

\begin{tabular}{|c|c|c|}
\hline $\begin{array}{l}h_{\text {corr }} \\
\text { (cm) }\end{array}$ & $\begin{array}{c}i_{l} \\
(\mu \mathrm{A})\end{array}$ & $i_{l} / \sqrt{h_{\text {corr. }}}$ \\
\hline 48.6 & 0.64 & 0.092 \\
\hline 58.7 & 0.70 & 0.092 \\
\hline 68.7 & 0.77 & 0.093 \\
\hline
\end{tabular}

(a) $\left[\mathrm{Eu}^{3+}\right]: 1.0022_{7} \mathrm{mmol} / l, \quad\left[\mathrm{G}^{0}\right]: 5 \mathrm{mmol} / l$, $p \mathrm{H}=10.5, \quad \mu=0.1\left(\mathrm{NaClO}_{4}\right), \quad m^{2 / 3} \cdot t^{1 / 6}=1.774$

$\begin{array}{cccccc}h_{\text {corr. }} & i_{l} & i_{l} / \sqrt{h_{\text {corr. }}} & \left(\begin{array}{c}i_{t} \\ (\mathrm{~cm})\end{array}\right. & \begin{array}{c}i_{t} / \sqrt{h_{\text {corr. }}} \\ \left.{ }^{\mu} \mathrm{A}\right)\end{array} & i_{2} / \sqrt{h_{\text {corr. }}} \\ 48.6 & 0.60 & 0.086 & 1.20 & 0.172 & 0.086 \\ 58.7 & 0.66 & 0.087 & 1.30 & 0.170 & 0.084 \\ 68.7 & 0.72 & 0.087 & 1.40 & 0.170 & 0.082\end{array}$

(b) $\left[\mathrm{Eu}^{3+}\right]: 1.002_{7} \mathrm{mmol} / l, \quad\left[\mathrm{G}^{0}\right]: 40 \mathrm{mmol} / l$, $p \mathrm{H}=10.5, \quad \mu=0.1\left(\mathrm{NaClO}_{4}\right), \quad m^{2 / 3} \cdot t^{1 / 6}=1.774$

注 $i_{l}+i_{2}=i_{t}, \quad i_{l}$ : 第一波， $i_{2}$ ：第二波を示す

$3.2 .4 p H$ の影響： [G0]：5，40 mmol $/ l$ にそれぞれ一定に して, $\left[\mathrm{Eu}^{3+}\right]: 1.002_{7} \mathrm{mmol} / l$ のとき, $0.1 \mathrm{~mol} / l$ 水酸化ナトリ ウムおよび $0.1 \mathrm{~mol} / l$ 塩酸を添加して $\left(\mu=0.1\left(\mathrm{NaClO}_{4}\right)\right), \quad p H$ の影響について検討した。 $\left[\mathrm{Eu}^{3+}\right]$ と $\left[\mathrm{G}^{0}\right]$ の濃度比が $1: 5$ の場 合は $6.65<p \mathrm{H}<8.00$ で錯体の波の前波として錯体を形成しつつ ある波を生じる。さらにつづいて極大波が $6.65<p H<9.80$ まで つづく。つぎに $p \mathrm{H}>10.15$ では極大波は消失して錯体の波と第 二波のみとなる。すなわち二段波となる(図 3 のa，図 4)。また 交流ポーラログラムによると， $6.65<p \mathrm{H}<9.05$ ではピーク電位 $-0.600 \mathrm{~V}$ vs. SCE の波が一つ，つぎに直流ポーラログラムの極 大波の電位付近に鋭いピークとそれに重なる肩をもつ波を生じる $(6.65<p \mathrm{H}<9.80,-1.235 \sim-1.450 \mathrm{~V}$ vs. SCE)。さらに $\mathrm{pH}$ が增加すると交流のピークは一つになり，幅広になってくる(図 5 参照)。

$p \mathrm{H}$ に刘し引(イオンの波打よび極大波の電位执よび第一波，第 二波の半波電位， $E_{\mathrm{S}}, E_{\max },\left(E_{1 / 2}\right)_{\mathrm{I}},\left(E_{1 / 2}\right)_{\mathrm{II}}$ をそれぞれプロッ 


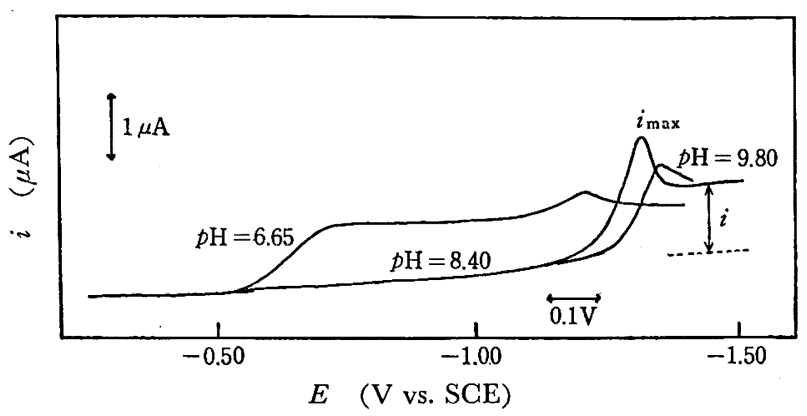

$\left[\mathrm{Eu}^{3+}\right]: 1.002_{7} \mathrm{mmol} / l, \quad\left[\mathrm{G}^{0}\right]: 5.0 \mathrm{mmol} / l$ $\mu=0.1\left(\mathrm{NaClO}_{4}\right)$

図 4 直流ポーラログラム $(p \mathrm{H}$ の影響)

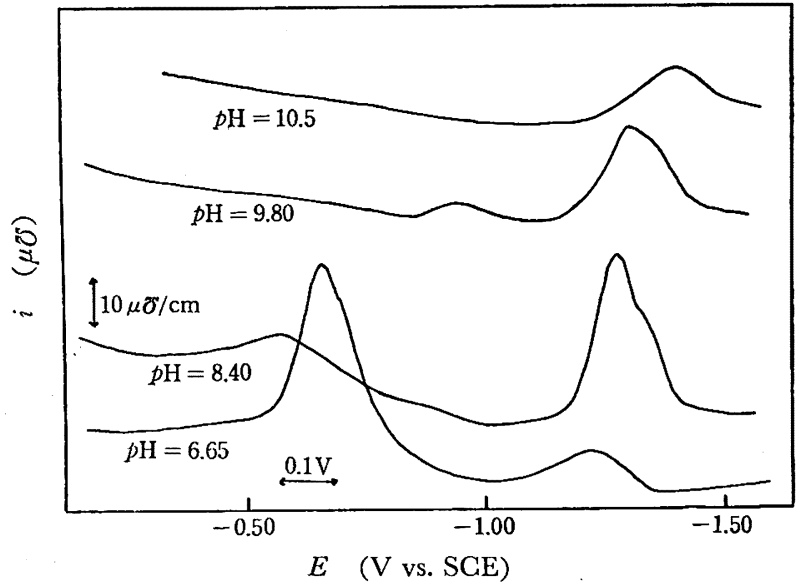

$\left[\mathrm{Eu}^{3+}\right]: 1.002_{7} \mathrm{mmol} / l, \quad\left[\mathrm{G}^{0}\right]: 5.0 \mathrm{mmol} / l$ $\mu=0.1\left(\mathrm{NaClO}_{4}\right)$

図 5 交流ポーラログラム $(p \mathrm{H}$ の影響 $)$

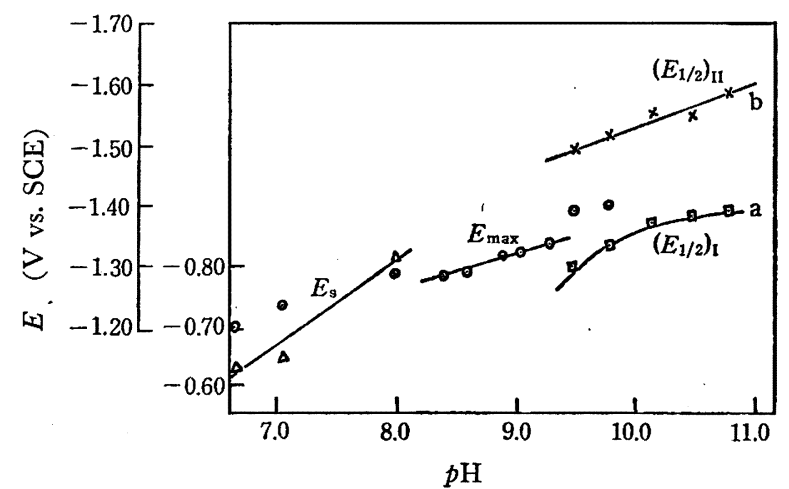

$\mathrm{a}:\left(\frac{\partial\left(E_{1 / 2}\right)_{\mathrm{II}}}{\partial p \mathrm{H}}\right)_{\left[\mathrm{G}^{0}\right]}=-0.070$

$\mathrm{b}:\left(\frac{\partial\left(E_{1 / 2}\right)_{\mathrm{I}}}{\partial p \mathrm{H}}\right)_{\left[\mathrm{G}^{0}\right]} \fallingdotseq 0$

$\left[\mathrm{Eu}^{3+}\right]: 1.002_{7} \mathrm{mmol} / l, \quad\left[\mathrm{G}^{0}\right]: 5 \mathrm{mmol} / l$ $\mu=0.1\left(\mathrm{NaClO}_{4}\right)$

図 6 pH の 影 響

トすると図 6 がえられる。この結果から二つの領域に区分され る。すなわち $8.0<p \mathrm{H}<9.3$ と $9.50<p \mathrm{H}<10.8$ の領域である。 前者では極大波が现われているが，後者では鍇体が矢定に存在与 る領域である。

$8.0<p \mathrm{H}<9.30$ では $E_{\max }$ (愥大波電位)は $p \mathrm{H}$ の增加ととも
に比例的に增加する(また同様に交流のピーク雪位も增加与る)。

$$
\partial E_{\max } / \partial p \mathrm{H}=-0.056 \mathrm{~V}
$$

をえる。

さらに $9.5<p \mathrm{H}<10.80,\left(E_{1 / 2}\right)_{\mathrm{I}}$ は $p \mathrm{H}$ の增加とともに增加 寸るが， $10.15<p \mathrm{H}$ になると变化しなくなる。

$$
\begin{array}{lc}
\partial\left(E_{1 / 2}\right)_{\mathrm{I}} / \partial p \mathrm{H}=-0.100 \mathrm{~V} & (9.50 \leq p \mathrm{H}<10.15) \\
\partial\left(E_{1 / 2}\right)_{\mathrm{I}} / \partial p \mathrm{H}=0 \mathrm{~V} & (10.15 \leq p \mathrm{H} \leq 10.8)
\end{array}
$$

また第二波の $\left(E_{1 / 2}\right)_{\mathrm{II}}$ は $p \mathrm{H}$ に比例して増加与る。符二波の半 波電位が -1.49 〜 $-1.58 \mathrm{~V}$ vs. SCE に存在する点で水絜イオン の還元電位に近い。しかもこの波が $p \mathrm{H}$ に依存しているので，シ ニウ酸，酒石酸のプロトンの還元と同じく弱酸，水和鍇イオンの 解雖によって生じたプロトン，

$\left[\mathrm{EuG}\left(\mathrm{H}_{2} \mathrm{O}\right)_{3}\right]^{2+} \rightleftarrows\left[\mathrm{EuG}\left(\mathrm{H}_{2} \mathrm{O}\right)_{2}(\mathrm{OH})\right]^{+}+\mathrm{H}^{+}$

の還元と推定される。

$$
\partial\left(E_{1 / 2}\right)_{\mathrm{II}} / \partial p \mathrm{H}=-0.070 \mathrm{~V}
$$

をえた。

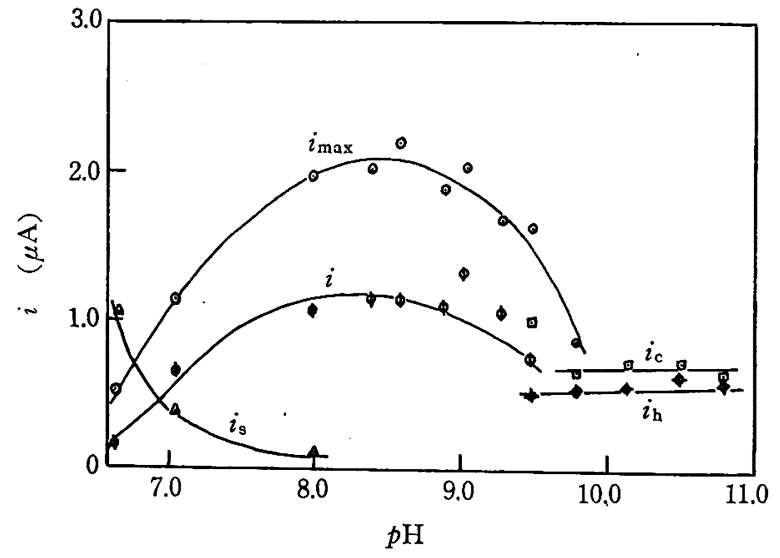

$i_{\mathrm{s}}$ : 単イオンの波高, $i_{\max }, i:$ 図 4 参照 $i_{\mathrm{c}}$ : 鍇体の波高, $i_{\mathrm{n}}$ ：第二波の波高 $\left[\mathrm{Eu}^{3+}\right]: 1.002_{7} \mathrm{mmol} / l, \quad\left[\mathrm{G}^{0}\right]=5 \mathrm{mmol} / l$ $\mu=0.1\left(\mathrm{NaClO}_{4}\right)$

図 $7 \quad p \mathrm{H} \quad$ の 影 篦

さらに $p \mathrm{H}$ に対して電流値をプロットナると図 7 をえる。ここ で $i_{\mathrm{S}}$ はユーロピウム $(\mathbb{I I})$ の波， $i_{\max }$ は㥛大波，i は㥛大波苍示 す波の限界電流值， $i_{\mathrm{c}}$ 性鍇体の第一波， $i_{\mathrm{h}}$ は符二波の艺机でれの 電流を示す。これは電位対 $p \mathrm{H}$ に関する関係と相関をもち，8.0 $<p \mathrm{H}<9.30,9.5<p \mathrm{H}<10.8$ の二領域における電流值の装化に しぼられる。

すなわ極大波が生じているとこると鍇体が安定に存在する領 域とである。 $8.0<p \mathrm{H}<9.3$ (極大波) と $9.8 \leq p \mathrm{H} \leq 10.5$ で電流值 は一定值となる。さらにグルコサミン酸浱度が過剩の場合の $p \mathrm{H}$ の影響を検討した。 $\left[\mathrm{Eu}^{3+}\right]:\left[\mathrm{G}^{0}\right]=1: 40$ 比であり，8.0<pH $<11.20$ 宋で変化した。 $8.0<p \mathrm{H}<9.35,9.8<p \mathrm{H}<11.2$ の二 領域が考えられ，前者では二段波芫生じ，第一波は鍇体の還元波 と考えられるが，第二波は加水分解によって生じたブロトンの還 元波と考允られる。後者は一波のみである。

$\partial\left(E_{1 / 2}\right)_{\mathrm{I}} / \partial p \mathrm{H}=-0.023 \mathrm{~V}(8.0<p \mathrm{H}<9.35)$
$\partial\left(E_{1 / 2}\right)_{\mathrm{II}} / \partial p \mathrm{H}=-0.085 \mathrm{~V}(8.0<p \mathrm{H}<9.35)$ (図 8 参照)

後者では 


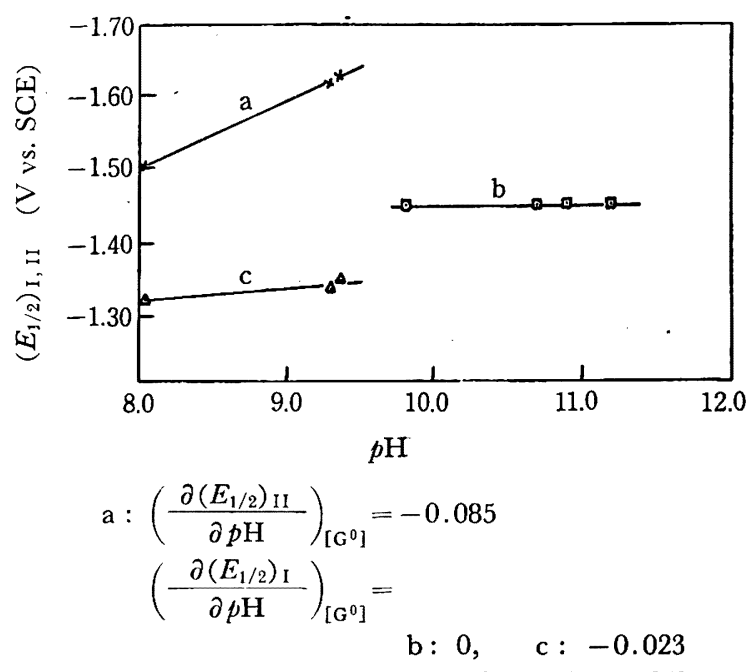

$\left[\mathrm{Eu}^{3+}\right]: 1.002_{7} \mathrm{mmol} / l, \quad\left[\mathrm{G}^{0}\right]: 40 \mathrm{mmol} / l$ $\mu=0.1\left(\mathrm{NaClO}_{4}\right)$

図 8 pH $\quad$ の 影 響

$\partial\left(E_{1 / 2}\right)_{\mathrm{I}} / \partial p \mathrm{H}=0 \mathrm{~V} \quad(9.8<p \mathrm{H}<11.2) \quad$ (図 8 参照)

すなわち $p \mathrm{H}$ の增加で $\left(E_{1 / 2}\right)_{\mathrm{I}}$ は一定である。また電流值は 9.80 までは $p \mathrm{H}$ の增加とともに增加し，9.80 $\leq p \mathrm{H}<10.90$ まで一定 となり，さらに $p \mathrm{H}$ が增加すると減少を示す。安定な錯体が 9.80 $\leq p \mathrm{H}<10.90$ で存在する。錯体の還元波の波形解析によると， $9.80<p \mathrm{H}<10.90$ で $84 \mathrm{mV}$ (平均值)，すなわち $n \alpha=0.70_{5}$ を 元た。な敃二波は $90 \mathrm{mV}$ から $48 \mathrm{mV}$ まで変化し，完全に非 可近性で $p \mathrm{H}$ に依你している(表 2 参照)。

表 $2 p \mathrm{H}$ の 影 響

$\left[\mathrm{Eu}^{3+}\right]: 1.002_{7} \mathrm{mmol} / l, \quad\left[\mathrm{G}^{0}\right]: 40 \mathrm{mmol} / l$ $\mu=0.1\left(\mathrm{NaClO}_{4}\right), \quad m^{2 / 3} \cdot t^{1 / 6}=1.774$

\begin{tabular}{|c|c|c|c|c|}
\hline$\left(E_{1 / 2}\right)_{\mathrm{I}}$ & $\left(E_{1 / 2}\right)_{\mathrm{II}}$ & $i_{\mathrm{c}}$ & $i_{\mathrm{h}}$ & $\log \underset{(\mathrm{mV})}{\text { プロット }}$ \\
\hline vs. SCE) & (V vs. SCE) & $(\mu \mathrm{A})$ & $(\mu \mathrm{A})$ & $S_{\mathrm{c}}$ \\
\hline
\end{tabular}

\begin{tabular}{rcccccc}
\multicolumn{1}{c}{$p \mathrm{H}$} & & & & & & \\
\cline { 5 - 7 } & $(\mathrm{V}$ vs. SCE $)$ & $(\mathrm{V}$ vs. SGE $)$ & $(\mu \mathrm{A})$ & $(\mu \mathrm{A})$ & $S_{\mathrm{c}}$ & $S_{\mathrm{h}}$ \\
8.00 & -1.325 & -1.505 & 0.16 & 0.48 & 90 & 90 \\
9.30 & -1.342 & -1.616 & 0.18 & 0.31 & 96 & 48 \\
9.35 & -1.352 & -1.628 & 0.23 & 0.35 & 102 & 62 \\
9.80 & -1.452 & - & 0.60 & - & 86 & - \\
10.70 & -1.454 & - & 0.62 & - & 80 & - \\
10.90 & -1.458 & - & 0.62 & - & 85 & - \\
11.20 & -1.459 & - & 0.64 & - & 84 & -
\end{tabular}

3.2 .5 グルコサミン酸濃度の影響： $p \mathrm{H}$ の影響の検討から 9.5 $<p \mathrm{H}<10.8$ で安定な錯体が形成されることがわかったので，こ の㑯域に才いてグルコサミン酸の浱度の影響について検討した。

末ず最初に $\left[\mathrm{Eu}^{3+}\right]: 1.002_{7} \mathrm{mmol} / l, p \mathrm{H}=9.70, \mu=0.1(\mathrm{Na}$ $\left.\mathrm{ClO}_{4}\right)$ の条作のもとにグルコサミン酸搌度 $\left[\mathrm{G}^{0}\right]$ を $0.2 \mathrm{mmol} / \mathrm{l}$ か ら $8.5 \mathrm{mmol} / l$ まで変化させた。 $0.5 \mathrm{mmol} / l$ までは鍇体の還元 波の前に $-1.15 \mathrm{~V}$ vs. SGE に波を生じる。これは完全に鍇体が 形成されずに遊雖のユーロピウム (III)が残っているために生じた ものと考兄られる。[G0]が $2 \mathrm{mmol} / l$ 以上になるとこの波は消失 して錯体の還元波のみとなり， $4 \mathrm{mmol} / l$ 以上になると第二波が 现わ机。

いま $\log \left[\mathrm{G}^{0}\right]$ に刘して $\left(E_{1 / 2}\right)_{\mathrm{I}}$ および $\left(E_{1 / 2}\right)_{\mathrm{II}}$ をプロットする

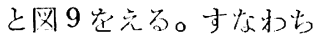

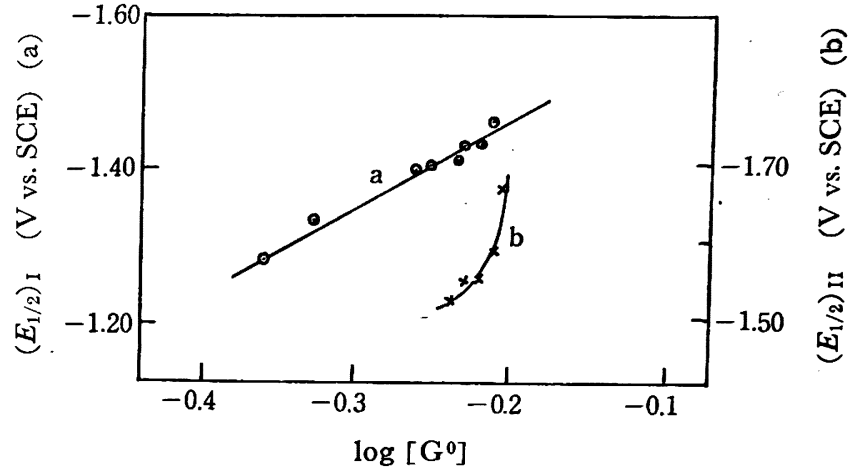

$\mathrm{a}:\left(\frac{\partial\left(E_{1 / 2}\right)_{\mathrm{I}}}{\partial \log \left[\mathrm{G}^{0}\right]}\right)_{p \mathrm{H}}=-0.102$

b : $\left(E_{1 / 2}\right)_{\text {II }}$

$\left[\mathrm{Eu}^{3+}\right]: 1.002_{7} \mathrm{mmol} / l, \quad p \mathrm{H}=9.70, \mu=0.1\left(\mathrm{NaClO}_{4}\right)$ 図 9 D-グルコサミン酸濃度の影響

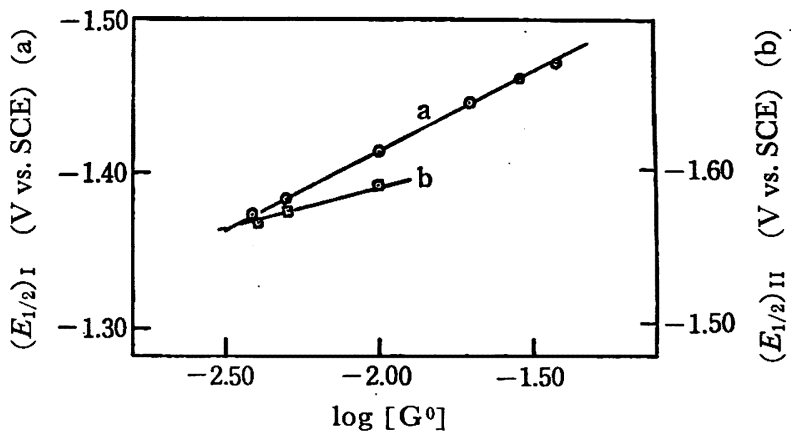

$\mathrm{a}:\left(\frac{\partial\left(E_{1 / 2}\right)_{\mathrm{I}}}{\partial \log \left[\mathrm{G}^{0}\right]}\right)_{p \mathrm{H}}=-0.102$
$\mathrm{~b}:\left(\frac{\partial\left(E_{1 / 2}\right)_{\mathrm{II}}}{\partial \log \left[\mathrm{G}^{0}\right]}\right)_{p \mathrm{H}}=-0.057$

$\left[\mathrm{Eu}^{3+}\right]: 1.002_{7} \mathrm{mmol} / l, p \mathrm{H}=10.5, \mu=0.1\left(\mathrm{NaClO}_{4}\right)$ 図 10 D-グルコサミン酸濃度の影響

$\left(\partial\left(E_{1 / 2}\right)_{\mathrm{r}} / \partial \log \left[\mathrm{G}^{0}\right]\right)_{p \mathrm{H}}=-0.102 \mathrm{~V}$

$\left(2 \mathrm{mmol} / l<\left[\mathrm{G}^{0}\right]<8.5 \mathrm{mmol} / \mathrm{l}\right)$

電極反応は非可逆性還元である。

第二波については

$\left(\partial\left(E_{1 / 2}\right)_{\mathrm{II}} / \partial \log \left[\mathrm{G}^{0}\right]\right)_{p \mathrm{H}}=-0.023 \mathrm{~V}$

$\log$ プロットの結果は $23 \mathrm{mV}$ である。限界電流はあまり一定 值を示していない。鍇イオン種が一定していないためと考えられ る。つぎに $p \mathrm{H}$ がさらに高い 10.5 においてグルコサミン酸濃度 について検討した。安定な錯体の形成が考えられる $p \mathrm{H}=10.5$ で $\left(E_{1 / 2}\right)_{\text {I }}$ に対して, $\log \left[\mathrm{G}^{0}\right]$ をプロットすると図 10 がえられる。 $\left(\partial\left(E_{1 / 2}\right)_{\mathrm{I}} / \partial \log \left[\mathrm{G}^{0}\right]\right)_{p \mathrm{H}}=-0.102 \mathrm{~V}$

$\left(4 \mathrm{mmol} / l<\left[\mathrm{G}^{0}\right]<40 \mathrm{mmol} / l\right)$

$\left[\operatorname{EuG}_{N}\left(\mathrm{H}_{2} \mathrm{O}\right)_{x}\right]^{(3-N)+}+e^{-} \rightleftarrows$

$\left[\operatorname{EuG}_{P}\left(\mathrm{H}_{2} \mathrm{O}\right)_{y}\right]^{(2-P)+}+(N-P) \mathrm{G}^{-}+(x-y) \mathrm{H}_{2} \mathrm{O}$

これから $N-P=1$ (逆傾斜: $84 \mathrm{mV}$ )なる值をえた。

さらに第二波に対して同様のプロットを行なうと

$\left(\partial\left(E_{1 / 2}\right)_{\mathrm{II}} / \partial \log \left[\mathrm{G}^{0}\right]\right)_{p \mathrm{H}}=-0.057 \mathrm{~V}(\log$ プロット $45 \mathrm{mV})$ 限界電流值は 4〜 $10 \mathrm{mmol} / l$ までは一定值を示すが, 20,30 $\mathrm{mmol} / l$ では減少を示し, さらに $40 \mathrm{mmol} / l$ になると增大する。 これは鍇イオン 種がいくぶん $\left[\mathbf{G}^{0}\right]$ とともに変化することを暗示 している。 
3.2 .6 ユーロピウム(III)-D-グルコサミン酸錯体のオッシロ ポーラログラフィー：P 576 ボーラロスコープ， $i_{0}=0.1 \mathrm{~mA} /$ $\mathrm{cm}^{2}, h=60 \mathrm{~cm}, m=1.595 \mathrm{mg} / \mathrm{sec}, t=4.5 \mathrm{sec}$, 温度 $25^{\circ} \mathrm{C}$ に一定にしてオッシロポーラログラムをとった。カメラ(アサヒペン タックス) $35 \mathrm{~mm}, \mathrm{X}$ 線フィルム总使用した。

まずユーロピウム（II）を含まないグルコサミン酸 $5 \mathrm{mmol} / \mathrm{l}$, $\mu=0.1\left(\mathrm{NaClO}_{4}\right)$ に一定にし， $\mu \mathrm{H}=10.5$ でえられたオッシロポ 一ラログラム $\mathrm{d} V / \mathrm{d} t=f(V)$ 曲線を図 11 の 1 に示している。ま たこのポーラログラムは $40 \mathrm{mmol} / \mathrm{l}$ グルコサミン酸のときむ同 じ形である。つぎにユーロピウム(II)を $0.1 \mathrm{~mol} / l\left(\mathrm{NaClO}_{4}\right)$ の 中でオッシロポーラログラム $(p \mathrm{H}$ 6.0)をとると図 11 の 2 をえ る。グルコサミン酸 $5 \mathrm{mmol} / l$ Kユーロピウム(II)を $1 \mathrm{mmol} / l$ 添加し, $\mu=0.1$ に一定にして, $p \mathrm{H}$ を 8.7 から 11.05 まで变 化してえられる結果を图 11 の3から図11 の6 まで示した。乙 れによると低い $\boldsymbol{p H}$ では陰極側に二つの切れ込みがえられ，陽極 側には一つの切れ込みがえられる。すなわち非可逆性の電極過程 を示している。 $p \mathrm{H}=10.3$ 以上になると陰極側の切れ込みは一つ だけとなり，陽極側は一つの切れ込みのままである。これを表 3（1）にまとめた。 $\rho \mathrm{H}$ が增加すると鍇体の還元の切れ込みのみと なる。つぎ $p \mathrm{H}=10.5$ に一定にして $5 \mathrm{mmol} / l$ から $40 \mathrm{mmol} /$ $l$ と[G00]変化して,オッシロポーラログラムをとると表 3-(2) の結果がえられた。これによると陰極側の切れ込みは一つで，酸 化側の切れ込みも一っで，明らかに両方の切れ込みの位置は等し くなく非可逆性の還元，酸化を示し，ら゙ルコサミン酸漘度の增加 で電位も負側へ移行している(図 12 の 1 3 参照)。

表 3 ユーロピウム（鱼）-D-グルコサミン酸鍇体の オッシロポーラログラム $\mathrm{d} V / \mathrm{d} t=f(V)$ 曲線

(1) $\left[\mathrm{Eu}^{3+}\right]: 1.002_{7} \mathrm{mmol} / l, \quad\left[\mathrm{G}^{0}\right]: 5.0 \mathrm{mmol} / l$, $\mu=0.1\left(\mathrm{NaClO}_{4}\right), \quad m^{2 / 3} \cdot t^{1 / 6}=1.754$

$p \mathrm{H}$

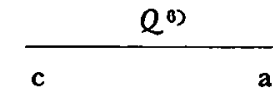

8.7

9.7

10.3

10.5

11.05

$6.0^{*}$

(2)

$\begin{array}{lcc}0.71, & 0.79 & 0.34 \\ 0.71_{5}, & 0.78_{6} & 0.34 \\ 0.75 & - & 0.33 \\ 0.75 & - & 0.35^{2} \\ 0.78_{3} & - & 0.36^{2} \\ 0.55, & 0.74 & 0.36_{6}\end{array}$

$\frac{\mathrm{d} V / \mathrm{d} t(\mathrm{~V} / \mathrm{sec})}{\mathrm{c}}$

$145,152 \quad 131$

$166,186.5$

111

111

111

166,207
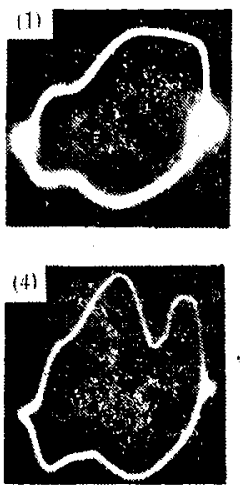

pH

l 10.5

26.0

$3 \quad 8.7$

$4 \quad 9.7$

$5 \quad 10.5$

$6 \quad 11.05$

図 11 オッシロポーラログラム $\mathrm{d} V / \mathrm{d} t=f(V)$ 怕線

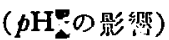
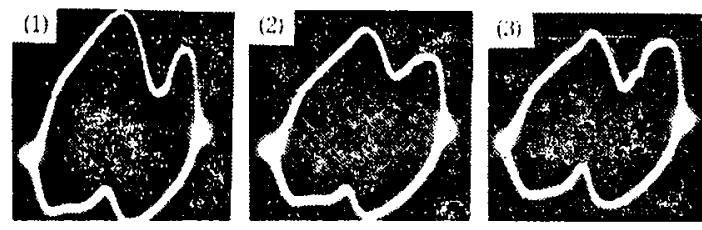

$p \mathrm{H}$

$\left[\mathrm{Eu}^{3+}\right](\mathrm{mmol} / l)$

$1 \quad 10.5$

$2 \quad 10.5$

$1.002_{i}$

$1.002_{7}$

9.0

$1.002_{7}$

$10 \sim 25$
40

40

0.1

0.1

0.1

因 12 オッシロポーラログラム $\mathrm{d} V / \mathrm{d} t=f(V)$ 功線 (Dーグルコサミン酸滉度の影留)

3.2.7 i t (電流-時間) 曲線: $\left[\mathrm{Eu}^{3+}\right]: 1.002_{7} \mathrm{mmol} / l,\left[\mathrm{G}^{0}\right]$ : $5 \mathrm{mmol} / l, \mu=0.1\left(\mathrm{NaClO}_{4}\right)$ て $\rho \mathrm{H}=10.5$ と $p \mathrm{H}=9.05$ に条件 を一定にして $i \sim t$ 曲線を测定した。 $p \mathrm{H}=10.5$ では $i \sim t$ 曲線は 正常な曲線を示すが， $p \mathrm{H}=9.05$ の条件ではその曲緗に乱を生じ る。乱れの原因には，（1）界面限力の変化によって，润が大き く成長すると乱れを生じること，（2）二重層容量に変化がある

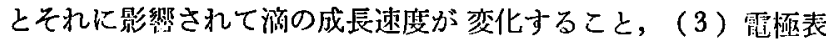
面への複極剂の佻給の仕方に変化があること，の三とおりが考光 られる。

このユーロピウム (III)ーD-グルコサミン酸錯体では䤵体の扣水 分解によって生じたヒドロキソ鍇体が雪極表面への複㥛剂の佻給 を阻害し，界面㖘力の変化を生じたためにi〜 $t$ 曲線に乱れを生じ たと考えられる(四 13 の a , b参照)。

3.2.8 電極反応過程と錯体の構造：䨪㥛反応過程を众討した。 $8.0<p \mathrm{H}<9.8$ の㖽城に执いては錯イオン程が安定に存在しにく w。

$$
\begin{aligned}
& \mathrm{GH} \rightleftarrows \mathrm{G}^{-}+\mathrm{H}^{+} \\
& \mathrm{G}^{-}+\mathrm{Eu}^{3+} \rightleftarrows \mathrm{EuG}^{2+} \\
& {\left[\mathrm{EuG}\left(\mathrm{H}_{2} \mathrm{O}\right)_{x}\right]^{2+} \rightleftarrows} \\
& \quad\left[\mathrm{EuG}\left(\mathrm{OH}_{2}\right)_{x-y}(\mathrm{OH})_{y}\right]^{2-y}+y \mathrm{H}^{+} \quad(y=1,2)
\end{aligned}
$$

極大波を生じる领域で忙 $\left[\mathrm{EuG}(\mathrm{OH})_{y}\left(\mathrm{H}_{2} \mathrm{O}\right)_{x-y}\right]^{2-y}(y=1,2)$ Messungen, Verlag Theodor Steinkopff, Dresden and Leipzig(1965)p. 20, 135. 
(a)

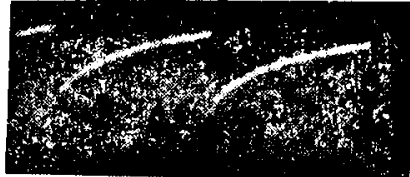

(b)

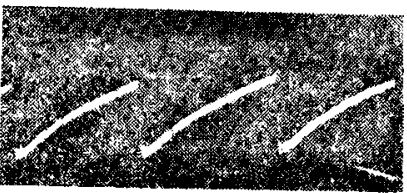

の雓体の霆情反応への参与が考えられ， $\mathrm{Eu}(\mathrm{OH}) y^{3-y}(y=1,2)$ の西㞹裴面への吸着が考えられる。i〜 $t$ 曲線からも推定される。 $p \mathrm{H}$ の影響の検討紝果から

$$
\begin{aligned}
& {\left[\mathrm{EuG}\left(\mathrm{H}_{2} \mathrm{O}\right)_{x-y}(\mathrm{OH})_{y}\right]^{2-y}+e \longrightarrow} \\
& \quad\left[\mathrm{Eu}(\mathrm{OH})_{y}\left(\mathrm{H}_{2} \mathrm{O}\right)_{x-y}\right]^{2-y}+\mathrm{G}^{-} \quad(y=1,2)
\end{aligned}
$$

条作 $9.8<p \mathrm{H}<10.8$ で $\left(E_{1 / 2}\right)_{1}$ の移行がない, $p \mathrm{H}=10.5$, $\left(\partial\left(E_{1 / 2}\right)_{\mathrm{r}} / \partial \log \left[\mathrm{G}^{0}\right]\right)_{p \mathrm{H}}=-0.102 \mathrm{~V}$ などから，溶液中に存在す る最大配位数 $N$ の鍇体之霓桠反応に関与する錯体の配位数 $\boldsymbol{P}$ の 样 $(N-P)=1$ であることが示され，電極過程では，

第一波では

$$
\begin{aligned}
& {\left[\mathrm{Eu}(\mathrm{G})_{2}\right]^{+} \rightleftarrows[\mathrm{EuG}]^{2+}+\mathrm{G}^{-}} \\
& {[\mathrm{EuG}]^{2+}+e \stackrel{\left(k_{f}^{0}\right)_{\mathbf{B}}}{\longrightarrow}[\mathrm{EuG}]^{+}}
\end{aligned}
$$

である。

第二波ではオッシロポーラログラム $\mathrm{d} V / \mathrm{d} t=f(V)$ 曲線から $p \mathrm{H}$ に你隹少えことがわかり， $\mathbf{H}+$ の電極反応への関与が考えられ る。それりえにユーロピウム（估）一D-グルコサミン酸鍇体の加 水分保によって生じたプロトンの䢬元波と推定される。

松仙綾部の式》

$$
\begin{aligned}
\left(E_{1 / 2}\right)_{\mathrm{I}} & =2.3 \frac{\boldsymbol{R} T}{n \alpha}\left\{\log \frac{\left(k_{f^{0}}\right)_{\mathrm{B}} f_{N}}{D_{N}{ }^{1 / 2}}\right. \\
& \left.+\frac{1}{2} \log t-0.053-(N-P) \log C_{x} f_{x}\right\}
\end{aligned}
$$

少ら

\section{恷作 $\quad p \mathrm{H}=10.5,\left[\mathrm{Eu}^{3+}\right]:\left[\mathrm{G}^{0}\right]=1: 5$ の場合}

$\left(E_{1 / 2}\right)_{\mathrm{I}}=-1.381 \mathrm{~V}$ vs. $\mathrm{SCE}=-1.135 \mathrm{~V}$ vs. $\mathrm{NHE}$

这傾斜值 $84 \mathrm{mV}$ (平均值), $n \alpha=0.70_{5}$

$\log C_{x}=-2.30, D_{N}^{1 / 2}=6.27 \times 10^{-4} \mathrm{~cm} / \mathrm{sec}^{1 / 2}$ (電流值を用

いIlkovič 式から求めた)

$t=4.5 \mathrm{sec}, N-P=1, f_{N}=f_{x}=1$ と仮定する.

$\left(k_{f}{ }^{0}\right)_{\mathrm{B}}=2.06 \times 10^{-15} \mathrm{~cm} / \mathrm{sec}$ をえる。

7) a) H. Matuda, Y. Ayabe, Z. Elektrochem., 63, 1164 (1959).

b) H. Matuda, Y. Ayabe, ibid., 66, 469(1962).

c) H. Matsuda, Y. Ayabe, Ber. Bunsenges. Physik. Chem., 67, 593(1963).

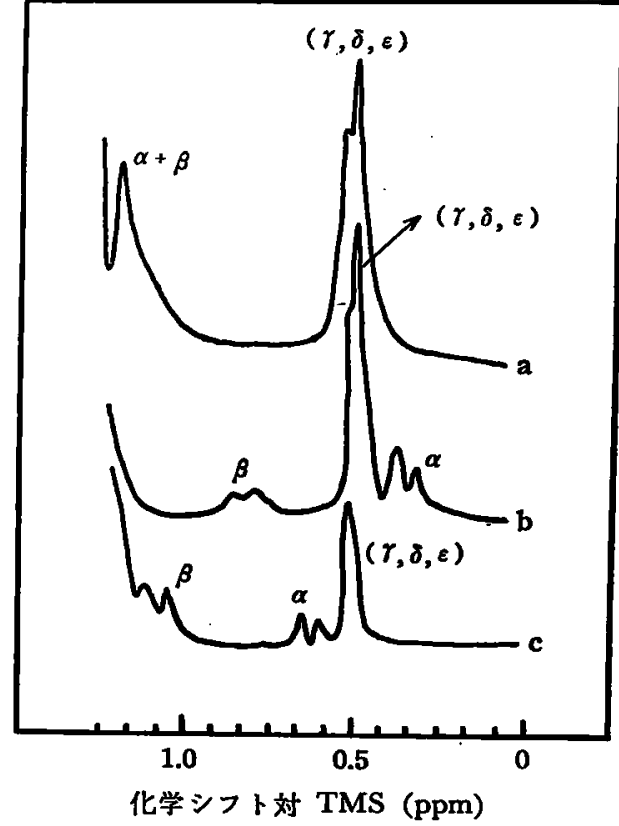

$a:\left[\mathrm{Eu}^{8+}\right]:\left[\mathrm{G}^{0}\right]=1: 5\left(\left[\mathrm{Eu}^{\mathrm{s}+}\right]: 0.04 \mathrm{~mol} / l\right), p \mathrm{D}=10.6$

$\mathrm{b}:\left[\mathrm{G}^{0}\right]=0.2 \mathrm{mmol} / l, p \mathrm{D}=10.6$

c: $\left[\mathrm{G}^{0}\right]=0.2 \mathrm{mmol} / l, p \mathrm{D}=6.4$

図 14 プロトン NMR スペクトル

条件 $p \mathrm{H}=10.5,\left[\mathrm{Eu}^{3+}\right]:\left[\mathrm{G}^{0}\right]=1: 40$ の場合

$\left(E_{1 / 2}\right)_{\mathrm{I}}=-1.468 \mathrm{~V}$ vs. $\mathrm{SGE}=-1.222 \mathrm{~V}$ vs. NHE

逆傾斜值 $84 \mathrm{mV}$ (平均值), $n \alpha=0.70_{5}$

$t=4.5 \mathrm{sec}, D_{N^{1 / 2}}=6.62 \times 10^{-4} \mathrm{~cm} / \mathrm{sec}^{1 / 2}, N-P=1$, $\log C_{z}=-1.40$

$f_{N}=f_{x}=1$ とする.

$\left(k_{f}^{0}\right)_{\mathrm{B}}=3.24 \times 10^{-17} \mathrm{~cm} / \mathrm{sec}$ をえる。

3.2.9 NMR 測定結果: 図 14 に示すように化学シフトから $\mathrm{D}$-グルコサミン酸の $\alpha, \beta$ および $(\gamma, \delta, \varepsilon)$ プロトンとユーロピウム (I)の相互作用があり， $\alpha>\beta>(\gamma, \delta, \varepsilon)$ プロトンの順序に強い結 合が生じていることが認められた。

それゆえに図 15 に示すような棈造が推定される。

$1: 1$ 鍇体, 1:2 錯体においては

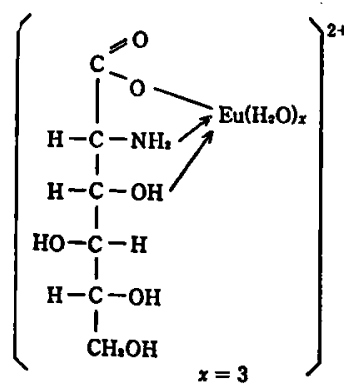

図 15-a

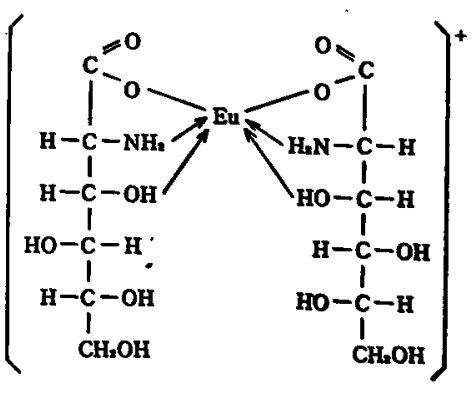

図 15-b
がえられる。

この研究の一部は科学研究費によって支出された。ここに文部 省に厚く感謝する。

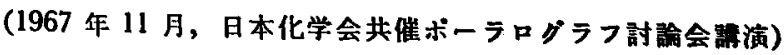

